\title{
An Analysis of Errors in Writing Skill of Adult Iranian EFL Learners Preparing for the IELTS
}

\author{
Nima Pouladian ${ }^{1}$, Mohammad Sadegh Bagheri ${ }^{1} \&$ Firooz Sadighi ${ }^{1}$ \\ ${ }^{1}$ Department of TEFL, Shiraz Branch, Islamic Azad University, Shiraz, Iran \\ Correspondence: Mohammad Sadegh Bagheri, Department of TEFL, Shiraz Branch, Islamic Azad University, \\ Shiraz, Iran. E-mail: bagheries@gmail.com
}

Received: November 30, 2016 Accepted: January 13, 2017 Online Published: February 9, 2017

doi:10.5539/ijel.v7n3p85 URL: http://dx.doi.org/10.5539/ijel.v7n3p85

\begin{abstract}
This study sought to examine the sort, frequency, and sources of writing wrongs committed by adult Iranian EFL students. To score the participants' written essays and speaking interviews, the four criteria specified for the IELTS Speaking and Writing Band Scores (British Council, 2014) were taken into consideration. The study also tried to comparatively analyze the error categories made by men and women learners regarding the type and frequency of their linguistic errors. To gather the information, from the population of faculty members at Hormozgan University of Medical Sciences (HUMS) in Bandarabbas, Iran, 100 adults, both male and female, with their age ranging from 31 to 52, were selected using convenient sampling. Based on their previous IELTS band scores ranging from 4 to 6 , the members are separated into three groups.

The results of data analysis revealed that verb tense was the very common grammatical mistake done by members in all three groups. For the cohesion and coherence and lexical sub-categories, relative clauses and incorrect use of target lexical item were regarded as the most common categories of errors. Outcomes of Chi-Square analyses also showed substantial differences among errors committed by participants in different groups. Finally, the comparison between male and female participants' errors revealed that male participants made both written and spoken errors more than females. According to the results, recommendations, and any suggestions that are of importance to teachers and policymakers as well as to EFL learners are presented in detail.
\end{abstract}

Keywords: error analysis, band score descriptors, IELTS preparation, EFL, productive skills

\section{Introduction}

Complaints about poor productive skills (i.e., speaking and writing) of Iranian EFL learners have been commonly heard from the public, teachers and even students all over the country. The reason is claimed to be either the teachers' lack of competence in L2 teaching process or the learners who are not motivated to produce the language. As Sattari (2012) maintains, the Iran's education system should also take the responsibility for the EFL learners' deficiencies in productive skills as it is perceived not to present an effective educational system for L2 pedagogy.

The inadequate learning of English language system by L2 learners can be associated with the improper transference of L1 rules into the target language (Lightbown \& Spada, 2006). In this regard, Nunan (2001) stated that advocate of Contrastive Investigation assertion that there is a difference between the first and second language rules, errors are likely to occur due to the interference of L1 into L2 structural system. Richards \& Schmidt (2002) further argued that students' errors committed during the process of L2 learning are caused by a number of phenomena that involve extending models from the target language, borrowing patterns from the mother tongue, and showing purposes utilizing the grammar and words that are now known.

To examine the problem, some scholar and practitioners in the field (e.g., Ilomaki, 2005; Randall, 2005; Fontecha, Llach, \& Espinosa, 2005) have tried to explore the types and frequencies of learners' errors committed during their L2 learning process and to identify the sources and causes of these errors occurring in the language of different learners with various first languages. According to Corder (1974), teachers and practitioners of the field may be able to define specific areas that require support in the teaching process if they systematically analyze the type of errors committed by L2 learners. 


\section{Literature Review}

\subsection{Error Analysis}

Wrong investigation (EA) is settled with Stephen Pit Corder and colleagues in the 1960s and "of a collection of methods for recognizing, defining and describing students' mistakes" (Ellis \& Barkhuizen, 2005, p. 51). Based on Corder (1981), students' mistakes are significant in 3 steps: first, they give data about the language a student is applying; second, they provide data on whence a language is studied and lastly, they provide data to the student himself or herself as mistakes can be seen as a means the student applies to study. The wrong investigation too has pedagogical advantages as it provides helpful information for planning and carrying out the instruction/learning method.

When conducting a study according to the criminal research, a difference among errors and mistakes must be made. Mistakes are irregular, due to vision errors, physical states or mental conditions while errors are regular and write to the underlying understanding of the language or transitional ability (Gass \& Selinker, 2008). An error is "a grammatical style or organization of sorts, that in the same setting and under related forms of product, would, in all probability, not be provided by the lecturers' native teacher matches" (Lennon, 1991, p. 182). An error displays the learners' ability in L2. Based on Brown (2000), a mistake can be self-corrected while a wrong cannot. This means, given the time and chance, the learner should be able to change his/her mistake(s).

\subsection{Pedagogical Uses of Error Analysis}

Language education cannot be one of the results of EA. Investigation of students' mistakes has actual results on teaching-learning method. EA studies are carried out first, to recognize plans that students apply in language education, second, to identify the causes of learners' mistakes and third to collect data on current problems in language teaching as an aide to school or in a community of educational materials (Richards et al., 1992). Based on Keshavarz (1999) EFL lecturers, syllabus authors, and analysis constructors, profit from EA.

By investigating students' mistakes, educators can get a real understanding of the problematic areas for learners, and they can evaluate the effectiveness of their instruction methods and materials as well. Accordingly, utilizing more efficient education approaches and strategies, they can focus on these questionable areas. EA can give useful data for syllabus authors and real developers. Regarding learners' problems and mistakes, syllabus designers can focus on these parts.

Different pedagogical meaning of the wrong investigation is wrong to change and leaning towards mistakes. Models and causes of mistakes define the sort of feedback and practice and also support educators apply effective education tactics when encountering a wrong. Harmer (1998) proposed 3 levels are sustained by the instructor when mistakes happen: first listening to the student, then recognizing the difficulty and third fixing the mistake right in the very effective method.

Erdogan (2005) proposed that an authority of mistakes should be set so that educators can focus on the mistakes that may change communication and make a difference. In a nutshell, effective education methods and procedures, as well as common material, are required to remove learners' difficulties in education. For this purpose, problematical fields must be searched and examined thoroughly and naturally.

\subsection{Empirical Studies on Error Analysis}

It is an obvious fact that investigating the type and frequency of L2 students' errors, as a pedagogical approach in L2 learning process, has attracted the study of many students and practitioners of the area.

Greatest of the modern global education in the wrong investigation study either the exact kind of mistakes or the causes of mistakes made by men studying English and other international languages. For instance, Yin \& Ung (2012) examined mistakes made by ESL learners in their written task. They tried to investigate, define, and describe the cross-linguistic rule found in 50 written English articles of low ability learners, and to learn how the original language or mother tongue turned the property of English. The written parts were investigated for frame change in the fields of lexis, grammar and language provided. The results showed things that have been wrongly utilized due to the check from L1 and low learning of the target language. In their results, they recognized items like approach; invented words and slang; inappropriate use of tenses; omission of articles; and adjective morphology mistakes.

Focusing on the sort of mistakes in EFL learners' writing tasks, Lin (2002) also studied 26 articles from Taiwanese EFL learners studying at the university level. A result of 928 mistakes are discovered, between that sentence structures mistakes happened with the highest rate. Usually, the outcomes of this research showed that the 4 biggest mistake rates were sentence structures (30.43\%), incorrect verb forms (21.01\%), sentence parts 
(15.94\%), and incorrect use of words (15.94\%).

There have also been a number of domestic studies conducted on analyzing students' errors. For example, Sadeghi (2009) presented research on collocational variations between L1 and L2 and reported that $72.1 \%$ of high school students failed to apply collocations accurately. He more determined $83.75 \%$ of mistakes to interlingual check (Persian as L1) and 16.25\% of errors to intra-lingua check (English or other factors).

Extra new research, carried out with Karimnia \& Abbasi (2011), has presented a list of generally performed grammatical mistakes of both junior and senior undergraduate learners in different Iranian university setting. The list involves mistakes that fall into levels of tenses, direct-indirect topics, quantifiers and intensifiers, Word, articles, use of Persian structures, subject-verb agreement, relative clauses and relative pronouns.

Fazilatfar \& Jabbari (2012) studied examples of Iranian students' mistakes, improving feedback movements, and student uptake drew from records of audio-recordings of the primary and high intermediate classes of a language institute covering about 12 hours of communication between the learners and educators. About sorts of mistakes, grammatical mistakes are the very frequent mistake kind in the complete database; but, phonological and lexical mistakes are the smallest frequent mistakes individually.

Today, the internationally recognized proficiency tests like IELTS and TOEFL are particularly sought after in Iran as well as all over the world since many people are applying to English speaking universities and/or trying to immigrate to countries where English is the medium of communication.

The writing skill, on which the present study focuses, is the hotspots of language errors and since few studies could be found to have investigated these errors thoroughly in IELTS candidates, the main purpose of this study is to investigate the types and causes of errors in the use of English for IELTS Academic module that are frequently made by Iranian EFL students hoping to help candidates and their tutors in avoiding them.

For this purpose, the essays of the participants written for both Task 1 and Task 2 are analyzed according to the IELTS Writing Band Score Descriptors by the British Council in hope of achieving a common list of errors in production which can lead to better success of the applicants taking the test and instructors preparing them.

Gender is also considered as an influential factor underlying experimental studies conducted in the field of applied linguistics and as a substantial source of variation among language learners (Yazdani \& Ghafar Samar, 2010). However, few studies have tried to explore the impact of EFL learners' gender on the type and frequency of their written grammatical and lexical errors.

\section{Methodology}

Since it is impossible to find out the best approach empirically and logically to study the kind and frequency of writing and speaking mistakes made by EFL students (Blaxter, Hughes, \& Tight, 2001), the author decided to apply a qualitative paradigm in this study. Written texts and speaking interviews of EFL learners preparing for the IELTS test were collected as the required sample data. Sample interviews were taken from all participants according to the standard format of the IELTS test with three distinct parts which will be presented in details in the next parts. Meanwhile, sample written tasks were collected from the participants to be assessed by the researchers and two qualified raters in order to elicit the committed errors.

This research determined the qualitative analysis plan to be appropriate for the aim of study because, as Kruger (2003, p. 19) confirms, "Qualitative techniques enable us to summarize significant sources of data and promote connections beyond levels and over time". This research aimed to identify errors, the types and their frequency as well as the possible sources and causes of students' errors.

\subsection{Participants}

For the purpose of this study, using convenience sampling, 100 adult EFL learners participating in an IELTS preparation course in Hormozgan University of Medical Sciences (HUMS) in Bandarabbas, Iran were selected. The participants, all graduated with medical degrees, have all taken the actual IELTS test during the 6-month period prior to their participation in this course and are grouped according to their band score. Group A had 21 participants with a band score of 6, group B included 49 people with a recorded band score of 5 to 5.5 while the rest (30 participants) comprised group $\mathrm{C}$ with a band score of 4 to 4.5 .

All of the participants were native speakers of Farsi with their age ranging from 31 to $52(M=39.36, S D=4.0)$; the majority $(79 \%)$ had an age of 35-38. However, there were three 31-year old participants as the youngest participants within the selected sample and five 50 to 52 -year-old cases as the oldest ones.

Generally, there were 46 male and 54 female participants (46\% and 54\% respectively). Thirty-seven participants (37\%) had graduated from their $\mathrm{PhD}$ program and were university lecturers. The rest of the participants $(63 \%)$ 
were specialists (either residents, attends or fellows at HUMS).

English was considered as a foreign language for all of the participants. The background questionnaire used to obtain the participants' demographic information indicated that 87 participants $(87 \%)$ believed that they chose to sit the IELTS test because they considered the possibility of living or working in an English speaking country and it was a compulsory requirement for their application process. The remaining participants reported that they needed to take the test for pursuing higher education.

\subsection{Instruments}

The researchers attempted to take sample IELTS writing tasks 1 and 2 which were used to elicit learner errors. Totally, at least one interview and 2 sample writing task were taken from each participant constituting 200 writings as the material being used in this study for analyzing their errors. The written tasks were obtained during January 2015 as well. It is noteworthy that all participants had taken the actual IELTS test in the latter half of 2014.

\subsection{Procedures}

The participants were asked to prepare written tasks in the aforementioned time intervals. In all, 200 written samples were collected. After the completion of data-collection, error-classification and frequency-computations, the researchers commenced the qualitative and quantitative analysis of the obtained data using highlights of the already-existing literature on each error's possible causes and implications. The written tasks and interviews were analyzed by the researchers and two qualified raters (with inter-rater reliability of $r=0.98$ ).

\subsection{Data Analysis}

The data analysis process was divided into three main parts; first, the errors were analyzed based on the four criteria used for scoring IELTS Academic Writing module. In the investigation of the information, the largest rates for written mistakes made by the 3 proficiency groups were recognized. Besides, the gathered data are analyzed by studying the relationships and variations in the type and frequency of errors committed by male and female participants. Considering the written errors, the participants' essays and reports composed for both task 1 and task 2 of the test were carefully read and analyzed in terms of the Task Achievement, Cohesion and Coherence, and lexical Resources and Grammatical Range and Accuracy (according to IELTS band descriptors by the British Counsil).

In the next step, the type and frequency of writing errors were described by descriptive statistics to report the frequencies and percentages of each category of errors within each proficiency group. Moreover, a comparison was made between the type and frequency of errors committed by male and female students so as to identify the possible impact of gender on participants' performances.

Finally, According to the autcomes of Chi-square tests, the difference among errors of different categories and genders were assessed finding significant distinctions in the majority of cases.

\section{Results}

The most important criteria considered for scoring IELTS academic writing are Task Achievement, Integration and Coherence, Lexical Resource, and Grammatical Area and Precision (British Council, 2014). For the purpose of this study, the last three criteria were taken into account in the data analysis process.

\subsection{Grammatical Errors in Writing}

The first part of this segment deals with the outcome of the grammatical study of the mistakes in the writing of all three groups and the estimate of the rate with that they happen. The grammatical mistakes in this research are listed as results: verb tense, singular/plural markers, modal/auxiliary, prepositions, articles and pronouns, infinitive/gerund, subject-verb agreement, verb form, connection structure, sentence structure, and word selection (analyzed at both word and sentence levels). All of these subcategories will be analyzed within the writings of the three groups; i.e., Group A, Group B, and Group C.

The classification of grammatical errors for essays written by the participants in all groups is depicted in Table 1. 
Table 1. Grammatical error types * group crosstabulation

\begin{tabular}{|c|c|c|c|c|c|c|}
\hline & & & \multicolumn{3}{|c|}{ Group } & \multirow[b]{2}{*}{ Total } \\
\hline & & & $\mathrm{A}$ & $\mathrm{B}$ & $\mathrm{C}$ & \\
\hline \multirow[t]{24}{*}{ Grammatical Error Type } & Verb tense & Count & 29 & 55 & 94 & 178 \\
\hline & & $\%$ within Group & $15.4 \%$ & $11.9 \%$ & $17.4 \%$ & $15.0 \%$ \\
\hline & Modal/Auxiliary & Count & 24 & 59 & 45 & 128 \\
\hline & & $\%$ within Group & $12.8 \%$ & $12.8 \%$ & $8.3 \%$ & $10.8 \%$ \\
\hline & Subject-verb agreement & t Count & 20 & 65 & 62 & 147 \\
\hline & & $\%$ within Group & $10.6 \%$ & $14.1 \%$ & $11.5 \%$ & $12.4 \%$ \\
\hline & Singular/Plural form & Count & 19 & 30 & 76 & 125 \\
\hline & & $\%$ within Group & $10.1 \%$ & $6.5 \%$ & $14.0 \%$ & $10.5 \%$ \\
\hline & Infinitive/Gerund & Count & 19 & 19 & 21 & 59 \\
\hline & & $\%$ within Group & $10.1 \%$ & $4.1 \%$ & $3.9 \%$ & $5.0 \%$ \\
\hline & Pronoun & Count & 17 & 22 & 22 & 61 \\
\hline & & $\%$ within Group & $9.0 \%$ & $4.8 \%$ & $4.1 \%$ & $5.1 \%$ \\
\hline & Article & Count & 15 & 74 & 38 & 127 \\
\hline & & $\%$ within Group & $8.0 \%$ & $16.1 \%$ & $7.0 \%$ & $10.7 \%$ \\
\hline & Verb form & Count & 12 & 27 & 15 & 54 \\
\hline & & $\%$ within Group & $6.4 \%$ & $5.9 \%$ & $2.8 \%$ & $4.5 \%$ \\
\hline & Preposition & Count & 10 & 47 & 71 & 128 \\
\hline & & $\%$ within Group & $5.3 \%$ & $10.2 \%$ & $13.1 \%$ & $10.8 \%$ \\
\hline & Sentence structure & Count & 9 & 39 & 11 & 59 \\
\hline & & $\%$ within Group & $4.8 \%$ & $8.5 \%$ & $2.0 \%$ & $5.0 \%$ \\
\hline & Inappropriacy & Count & 8 & 15 & 33 & 56 \\
\hline & & $\%$ within Group & $4.3 \%$ & $3.3 \%$ & $6.1 \%$ & $4.7 \%$ \\
\hline & Comparison structure & Count & 6 & 9 & 53 & 68 \\
\hline & & $\%$ within Group & $3.2 \%$ & $2.0 \%$ & $9.8 \%$ & $5.7 \%$ \\
\hline \multirow[t]{2}{*}{ Total } & & Count & 188 & 461 & 541 & 1190 \\
\hline & & $\%$ within Group & $100.0 \%$ & $100.0 \%$ & $100.0 \%$ & $100.0 \%$ \\
\hline
\end{tabular}

The total number of errors of Group A was 342 from the 42 sample writing tasks obtained from the participants in this group. And their assignments based on their classifications are as displayed in the table. It is evident that the verb tense is the principal wrong category $(15.42 \%)$. Then, the second very frequent mistake was the modal/auxiliary kind $(12.76 \%)$. The subject-verb recognition failure $(10.63 \%)$ listed as the most common sort. Apart of these kinds of mistakes, the other wrong sections were: singular/plural form $(10.10 \%)$, infinitive/gerund $(10.10 \%)$, pronouns $(9.04 \%)$, article $(7.97 \%)$, verb form $(6.38 \%)$, preposition $(5.31 \%)$, sentence structure (4.78\%), in appropriacy (4.25\%), and comparison structure (3.19\%), respectively.

A total of 98 written scripts collected from the participants in group B. As displayed in Table 1, different group A, Singular/Plural was not reported as the most common mistake in the writings of Group B since the participants rarely made these errors due to better language knowledge. However, from the total of 1175 errors recorded in this group's scripts, the three most common mistakes are in their use of articles (16.05\%), Subject-Verb adjustment (14.09\%), and modal/auxiliary (12.79\%), nearly comparable to the mistakes in Group A, but for the class of grammars that has followed with that of infinitive/gerund. Interestingly, verb tense $(11.93 \%)$ became scholars' fourth most common difficulty when answering task 1 and task 2 prompts.

As can also be viewed of the information in Table 1 and participants in group $\mathrm{C}$ made many errors regarding comparison structures. Not surprisingly, verb tense (17.37\%), singular/plural mode (14.04\%), preposition (13.12\%), and subject-verb adjustment (11.46\%) were the four very common mistakes.

Given the type of data, Chi-Square analysis is conducted to define if there is a meaningful difference among errors in grammatical categories of the three groups of participants and with $p<0.001$, such a difference was observed as presented in Table 2 . 
Table 2. Chi-square tests

\begin{tabular}{llll}
\hline & Value & df & Asymp. Sig. (2-sided) \\
\hline Pearson Chi-Square & $134.738^{\mathrm{a}}$ & 22 & .000 \\
Likelihood Ratio & 135.215 & 22 & .000 \\
Linear-by-Linear Association & 3.256 & 1 & .071 \\
N of Valid Cases & 1190 & & \\
\hline
\end{tabular}

Note. ${ }^{\text {a }} 0$ cells $(0.0 \%)$ have expected count less than 5 . The minimum expected count is 8.53 .

\subsection{Coherence and Cohesion Errors in Writing}

The next criterion considered for analyzing the written errors of participants was the proper use of cohesive devices in the texts. The five fundamental categories explained by Halliday \& Hasan (1976) were reviewed and taken into consideration to regularly now a structure for the study of cohesive parts in this research. According to this analysis system, common wrong types which led to their departure from Standard English usage were fixed. The next segments will present the main types of error, which were frequent at the written texts of three groups of the study, respectively.

Table 3. Cohesion error categories * group crosstabulation

\begin{tabular}{|c|c|c|c|c|c|c|}
\hline & & & \multicolumn{3}{|c|}{ Group } & \multirow[b]{2}{*}{ Total } \\
\hline & & & A & $\mathrm{B}$ & $\mathrm{C}$ & \\
\hline \multirow{10}{*}{$\begin{array}{l}\text { Errors in } \\
\text { cohesion } \\
\text { categories }\end{array}$} & Reference & Count & 20 & 34 & 28 & 82 \\
\hline & & $\%$ within Group & $57.1 \%$ & $53.1 \%$ & $40.0 \%$ & $48.5 \%$ \\
\hline & Substitution & Count & 0 & 0 & 2 & 2 \\
\hline & & $\%$ within Group & $0.0 \%$ & $0.0 \%$ & $2.9 \%$ & $1.2 \%$ \\
\hline & Conjunction & Count & 1 & 4 & 6 & 11 \\
\hline & & $\%$ within Group & $2.9 \%$ & $6.3 \%$ & $8.6 \%$ & $6.5 \%$ \\
\hline & Lexical--Repetition & Count & 4 & 8 & 10 & 22 \\
\hline & & $\%$ within Group & $11.4 \%$ & $12.5 \%$ & $14.3 \%$ & $13.0 \%$ \\
\hline & Lexical--Collocation & Count & 10 & 18 & 24 & 52 \\
\hline & & $\%$ within Group & $28.6 \%$ & $28.1 \%$ & $34.3 \%$ & $30.8 \%$ \\
\hline \multirow[t]{2}{*}{ Total } & & Count & 35 & 64 & 70 & 169 \\
\hline & & $\%$ within Group & $100.0 \%$ & $100.0 \%$ & $100.0 \%$ & $100.0 \%$ \\
\hline
\end{tabular}

Investigating 42 scripts written by 21 group A participants identified 35 cohesive mistakes in that the method of references were the most common ones $(\mathrm{N}=20)$, accompanied by mistakes in lexical $(\mathrm{N}=14)$, and conjunctive cohesion $(\mathrm{N}=1)$. The outcomes displayed in Table 3 show the comparative extent to that the things from each section and subcategory of cohesion were utilized wrongly in performing overall cohesion commonly with a detailed analysis of the wrong investigation. Also, the cohesive referential devices are the most common mistakes committed by the participants of group A, with the lexical errors being the second most frequent category of errors. Furthermore, it is evident that the majority of the lexical mistakes are involved in collocation and repetition, respectively.

Secondly, from the 98 written scripts taken from 49 the participants in group B, a total number of 64 cohesive errors were specified. The results of data analysis indicated that mistakes in references are the very common ( $\mathrm{N}$ $=34)$, succeeded by lexical mistakes $(\mathrm{N}=26)$, and connection $(\mathrm{N}=4)$. As can be viewed in Table 3 , the very common errors made by participants in group B are in references and the next most common mistakes are the lexical slips. Table 3 shows that the majority of the lexical mistakes are designated to the collocation and repetition subcategories, respectively.

Thirdly, as is witnessed in Table 3, 70 errors were elicited in the submitted scripts of the 30 members in group C and among the total amount of mistakes, the most frequent errors committed by participants of this group were in lexical cohesion $(\mathrm{N}=34)$, references $(\mathrm{N}=28)$, conjunction cohesion $(\mathrm{N}=6)$, and substitution $(\mathrm{N}=2)$. Table 3 explains that the majority of the mistakes are in cohesive referential symbols and lexical class in group $\mathrm{C}$ participants' written texts. Besides, the preponderance of the very common mistakes; i.e., lexical errors, are devoted to the collocation and return subcategories.

Moreover, Table 4 demonstrates the results of Fisher's Exact Test on the data collected from the three groups regarding errors in cohesion categories: 
Table 4. Chi-square tests

\begin{tabular}{|c|c|c|c|c|c|c|}
\hline & Value & $\mathrm{df}$ & Asymp. Sig. (2-sided) & Exact Sig. (2-sided) & Exact Sig. (1-sided) & Point Probability \\
\hline Pearson Chi-Square & $6.522^{\mathrm{a}}$ & 8 & .589 & .606 & & \\
\hline Likelihood Ratio & 7.396 & 8 & .495 & .586 & & \\
\hline Fisher's Exact Test & 5.425 & & & .722 & & \\
\hline Linear-by-Linear Association & $1.427^{\mathrm{b}}$ & 1 & .232 & .237 & .119 & .006 \\
\hline $\mathrm{N}$ of Valid Cases & 169 & & & & & \\
\hline
\end{tabular}

Table 4 clearly reveals that according to Fisher's Exact Test, there is no significant difference between errors in the cohesion categories among three groups $(\mathrm{p}=0.772)$.

\subsection{Lexical Resource Errors in Writing}

To investigate the type and frequency of lexical errors committed by participants, this study used the taxonomy proposed by James (1998) who divides lexical errors in a well-ordered list based on the two major types of lexical errors. Based on the data, the researchers found two major types of lexical errors that consisted of 11 subtypes of formal errors and 3 subtypes of semantic errors. Table 5 provides the lexical errors distribution according to the types and subtypes found in the writings.

Table 5. Frequency and percentage of lexical errors in all groups

\begin{tabular}{lllll}
\hline Type of error & & & Frequency & Percentage \\
\hline A. Formal Errors & Formal Misselection & Suffix Type & 50 & 8.47 \\
& & Prefix Type & 2 & 0.33 \\
& & Vowel-Based Type & 6 & 0.99 \\
& \multirow{4}{*}{ Formal Misformations } & Consonant-Based Type & 14 & 2.37 \\
& & Borrowing & 8 & 1.35 \\
& & Coinage & 2 & 0.33 \\
& Distortions & Calque & 212 & 35.93 \\
& & Omission & 88 & 14.91 \\
& & Overinclusion & 32 & 5.42 \\
& Misselection & 168 & 28.47 \\
& total & Misordering & 8 & 1.35 \\
& & Using a Superonym for a Hyponym & 4 & 73.93 \\
\hline B. Semantic Errors & Confusion of Sense & Using Inappropriate Co-Hyponyms & 100 & 4.92 \\
& Relations & Using Wrong Near Synonym & 104 & 50.07 \\
& & & 208 & 26.07 \\
\hline Total number of lexical errors & & 798 & 100 \\
\hline
\end{tabular}

According to the data, formal errors became the highest frequent errors found in the writings of all groups. Besides, the result on the production of formal errors provides an important issue where most of the participants seem to have a serious problem in determining the correct form of lexical items. Moreover, the errors classified as formal errors were mostly due to intralingual errors or intralingual transfer (this term was suggested by James, 1992; Brown, 2007).

Based on the results of this study, most of the participants possess a problem in determining the correct word class of lexical item due to the influence of intralingual error. The other problems which occurred in the students' essay writings because of the intralingual error are (1) the inappropriate use of suffix or prefix to examine the correct word class of lexical item, (2) the improper spelling of lexical items because of the addition or deletion of one item in the well-formed of one word and (3) a false analogy which affects the students in determining the plural form of lexical item.

Among the occurrences of formal errors sub-types, calque (the sub-type of formal misformation) became the most common lexical error found in the students' written texts. Even though the major problem of the students in lexical errors were derived from intralingual errors, the occurrences of calque in the students' narrative writings imply an important issue that most of the students also have a problem in transmitting their ideas to their written 
compositions because of the influence of L1. Besides, the students also seem to have limited vocabularies in the target language.

\subsection{Errors according to Gender}

To detect the difference between class and rate of linguistic mistakes made by man Iranian male and female EFL learners, the researchers examined male and female competitors' mistakes and the outcome is shown in Table 6.

Table 6. Types and frequencies of errors among male and female candidates

\begin{tabular}{llllll}
\hline \multirow{2}{*}{ Type of error } & & Gender & female & & male \\
& & Frequency & Percentage & Frequency & Percentage \\
\hline \multirow{2}{*}{ Writing } & Grammatical & 681 & 60.53 & 549 & 53.19 \\
& lexical & 363 & 32.26 & 395 & 38.27 \\
& Coherence/cohesion & 81 & 7.21 & 88 & 8.54 \\
Total & & 1125 & 100 & 1032 & 100 \\
\hline Speaking & Grammatical & 171 & 47.5 & 145 & 43.8 \\
& lexical & 65 & 18.05 & 79 & 23.86 \\
& Coherence/cohesion & 96 & 26.66 & 86 & 25.98 \\
& Collocation & 28 & 7.79 & 21 & 6.36 \\
\hline Total & & 360 & 100 & 331 & 100 \\
\hline
\end{tabular}

As it is presented in Table 6, male applicants made more mistakes than females in writing with 1125 and 1032 errors, respectively. As the figures in Table 6 reveal, male participants made more grammatical errors than females $(60.53 \%$ vs. $53.19 \%$, respectively) while female participants committed slightly more coherence and cohesion errors compared to males $(8.54 \%$ vs, $7.21 \%$, respectively). Table 7 contains an analysis of writing errors committed across genders:

Table 7. Writing errors * gender crosstabulation

\begin{tabular}{llllll}
\hline & & \multicolumn{2}{c}{ Gender } & \\
\cline { 3 - 4 } & & & female & male & Total \\
\hline \multirow{2}{*}{ Writing } & Grammatical & Count & 681 & 549 & 1230 \\
& \multirow{3}{*}{ lexical } & $\%$ within Gender & $60.5 \%$ & $53.2 \%$ & $57.0 \%$ \\
& & Count & 363 & 395 & 758 \\
& \multirow{3}{*}{ Coherence/cohesion } & \% within Gender & $32.3 \%$ & $38.3 \%$ & $35.1 \%$ \\
& & Count & 81 & 88 & 169 \\
& & $\%$ within Gender & $7.2 \%$ & $8.5 \%$ & $7.8 \%$ \\
\hline Total & & Count & 1125 & 1032 & 2157 \\
& & $\%$ within Gender & $100.0 \%$ & $100.0 \%$ & $100.0 \%$ \\
\hline
\end{tabular}

As is witnessed in Table 7, the total number of writing errors committed by male candidates outweighs that of females by just under 100 instances, with the majority of errors in both genders being grammatical $(60 \%$ and $53 \%$, respectively). The following table indicates the result of a Chi-square test to find out if there is a significant difference between writing errors across genders.

Table 8. Chi-square test of writing errors across genders

\begin{tabular}{llll}
\hline & Value & df & Asymp. Sig. (2-sided) \\
\hline Pearson Chi-Square & $11.819^{\mathrm{a}}$ & 2 & .003 \\
Likelihood Ratio & 11.824 & 2 & .003 \\
Linear-by-Linear Association & 9.929 & 1 & .002 \\
N of Valid Cases & 2157 & & \\
\hline
\end{tabular}

Note. ${ }^{\text {a. }} 0$ cells $(0.0 \%)$ have expected count less than 5 . The minimum expected count is 80.86 .

It is seen in Table 8 that there is a meaningful difference in the writing errors of males and females $(\mathrm{p}=0.003)$. 


\section{Discussion and Conclusion}

Firstly, the researchers tried to investigate the types of writing errors commonly made by learners preparing for IELTS test with different proficiency levels. Considering the IELTS Writing band descriptors, this study focused on three criteria for scoring learners' essays; namely, Coherence and Cohesion, Lexical Resource, and Grammatical Range and Accuracy (British Council, 2014).

According to the results of the now research, there was a meaningful difference in the amount of mistakes performed by any group. Participants in group $\mathrm{C}$ made the highest number of errors $(\mathrm{N}=541)$, which was followed by group B that committed a total of 461 errors and participants in group A recorded the lowest number of errors $(\mathrm{N}=188)$. These figures bear more meaning when considering the number of participants in each group. Group C comprised 60 participants in comparison with 98 and only 42 individuals in groups B and A, respectively. This is to say that although the number of group B participants was over $30 \%$ more than that of group $\mathrm{C}$, still there were more recorded written grammatical errors in the latter group.

In general, the results of this study indicated that verb tense was the most common error made by participants in all three groups, by the total of 178 mistakes listed. The report of this wrong number showed that incorrect use of verb tenses was the problem with all three groups' written texts. However, students with different proficiency levels made this type of error with different frequencies. participants in Group C had a total of 94 verb tense mistakes, that is the highest rate in comparison to Group B and Group A cases who made fewer wrong in this section, 55 and 29 verb tense mistakes individually (see Tables 1, 2, 3 and 4). These results may suggest that inappropriate use of verb tenses is one of the main learning difficulties for all three groups. However, it should be noted that some verb tense mistakes seem to be an outcome of negligence in writing rather than lack of L2 proficiency. To investigate the use of verb tenses, this study focused mostly on 2 areas; i.e., incorrect verb information applied and Past tense form usage where the now tense form is needed.

Generally, the results of data analysis showed that the errors made by the participants are caused by two major sources: i.e., interlingual errors, which occur as a result of L1 transfer, and intra-lingual errors, which occur due to the lack of L2 knowledge. A comparison of participants' errors in all three groups revealed that majority of participants at higher levels of language proficiency (i.e., Group A and Group B) made more intra-lingual errors than inter-lingual ones; whereas those in Group $\mathrm{C}$ with lower level of language proficiency made more inter-lingual errors due to the L1 interference. The reason behind this fact is that learners find more difficulty in learning English patterns that are similar to, but in some way different from patterns of their own language. The key to this problem in the lower level is the fact that they always resort to literal translation before they form English patterns. Put it differently, they translate one language phrase into another word for word (not phrase by phrase).

A detailed analysis of different types of errors committed by indicated that most mistakes happened as a outcomes of L1 arrest while some were due to improper preparation or lack of L2 knowledge. What is clear is that the strategies that participants employed indicated some features of L2 were studying method and learner interlanguage way. This finding is in order by the results of other experimental investigations (e.g., Abbasi \& Karimian, 2011; Sadeghi, 2009). Furthermore, it can be claimed if the L2 learners utilize the L1 grammatical properties and employ them when writing L2 structures, their use of first language grammatical structures will lead to mistakes in some circumstances and contribute to the gap between L1 and L2 lexical features. The results of this research also revealed that the Iranian EFL learners preparing for the IELTS test were not informed of rules underlying article writing of English. It was noticed that in common there are regular mistakes in students' purpose language.

Considering the sources of cohesion errors, many L2 researchers and practitioners (e.g., Hasyim, 2002; James, 1998; Richards, 1974) have concluded that there is a general distinction between interlingual and intralingual errors. Despite the fact that this analysis is not ever clear-cut, this research made a try to study the potential effectiveness of L2 overall language learning and L1 interference method on EFL students' causes of mistakes in applying cohesive devices. Besides, a number of related examples, showing the typical components by that the wrong source could be recognized, are provided in the analysis of the cases of mistakes so as to indicate any variation existing between the two sources of errors.

In general, the most common error type in cohesion was the incorrect use of references which occurred most frequently in learners' writing when using reference devices. This can be considered as a result of native language interference (in this case, Persian) since Persian does not make a distinction among pronouns, inappropriate, personal-, possessive pronouns, and specifics, for instance: 
- Mina went to the amusement park. He needed some enjoyment (she)

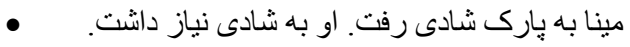

- Ali gave me a collection of flowers. She wanted to cheer me up (he)

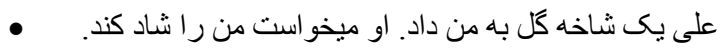

As these examples show, in Persian /? $\mathrm{u} /(\mathrm{g})$ is used for referring to both personal pronouns he and she in English. Moreover, /æsh/ الش) in Persian is employed for referring to the possessive pronouns her, his, their, and its in English as explained in the cases here:

My grandmother was ill. I got his pills. (her)

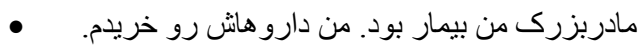

- She talked about them with his neighbor. (her)

• او درمورد آنها با همسايه اش صحبت كرد.

Furthermore, a reasonably wide difference of unidiomatic similar developed in the subcategory of collocation. Greatest of the interlinguas forms used for lexical cohesion show more common difficulties with the use of grammars, as in the samples below:

- We can explain this plan for the other state (describe sth to sb) He appreciates with this situation. (addition of preposition)

Regarding the sources of mistakes performed by Iranian EFL students preparing for the IELTS test, the inappropriate use of related pronouns and conjunctions, as well as various kinds of repetition, performed in learners' writings, which were attributed to the incomplete knowledge of the learners rather than their L1 interference. This outcome is compatible with those of Tabatabai (1985), Sattayatham \& Honsa (2007) and Ahmadvand (2008) who assumed that the most common students' mistakes were often independent of the student local language.

Concerning the type and frequency of lexical errors, the results of this study revealed that the most frequent type of errors made by EFL students were formal errors. Moreover, the result of this study indicated that most of the students seemed to have a serious problem in determining the correct form of lexical items. Besides, the errors classified as formal errors were mostly derived from intralingual error or interlingual transfer, as suggested by James (1998).

As the results revealed, many students experienced difficulty in specifying the correct form of the target lexical item as a result of intralingual error. The other problems which occurred in the students' IELTS writing essays due to the effect of intralingual error were the incorrect use of suffix or prefix to explore the correct form of lexical item, the incorrect spelling of lexical items due to the addition or omission of one item in the well-formed of one word, and a false analogy which influenced the learners' attitude in determining the plural form of lexical item.

Formal misformations became the most common lexical error found in the essay writings. Even though the major problem of the students in lexical errors were derived from intralingual errors, the occurrences of formal misformations in the texts revealed that most of the participants also had difficulty in transmitting their ideas to their written texts due to the influence of $\mathrm{L} 1$ interference.

The result of this study in formal errors contradicted the results of studies conducted by Shalaby, Yahya, \& El-Komi (2009) and Hemchua \& Schmitt (2006). In all of these studies, the results of lexical errors indicated that semantic error was the most frequent error found in the students' writings. The possible reason behind the difference between the results of this study with the other studies may be due to the characteristics of sample participants of the study. In the present study, the IELTS Candidates preparing for the test with different level of language proficiency were selected, who are different compared to the students at the university level that participated in the other studies.

As a whole, male applicants made more mistakes than women. On the other hand, female competitors still committed fewer mistakes regarding the total amount of errors, but they had more cohesion and coherence errors than males. This can be as of the fact that females, based on Holmes (1995) and McMillan (1977), intend to have more particular utterances and women's language is more complicated, few blunt, and has more prestigious forms. Also, as it is stated by Lackoff (1975) and Holmes (1995), women applied more hedges and tag problems than men which may make this mistake sort. Besides, Since 1970s many students such as Deborah Cameron, Penelope Eckert, and Janet Holmes began to study in language and gender and assumed that men and women use 
language against. The outcome of this section is in line with Saeed, Ramazan, Gujjar, \& Iqbal's (2011) study in which the researchers concluded that women are generally better language learners compared to men.

The findings of the present study can have implications for EFL learners, teachers, test developers and researchers. Being informed of the most common mistake classes as well as the primary mistake sources, educators can focus on the students' linguistic problems. Moreover, they can tell students about nature of their errors. Making advanced EFL learners notified of their most problematic areas can encourage them to concentrate on these errors and enhance their writing and speaking abilities (Tahririan, 1986). Being informed of the fields that they may have more problems, EFL learners can focus on those areas and analyze to develop their skills and experience about these incredible features. This can increase their awareness concerning the difficulties of the language education method.

According to Yaghoubi (2009), Educators can improve learners' mistakes correctly, and students can discover their mistakes and apply specific approaches in the domain of failure monitoring and wrong adjustment. Wrong introduction explains how students come by and take to their mistakes (Rybowiak et al., 1999). Error analysis Provides to learner-centered language pedagogy by presenting the education techniques closer to the teaching procedures. Since the gap between language learning and teaching can be filled by the wrong investigation (Mahmoud, 2011).

\section{References}

Abbasi, M., \& Karimnia, A. (2011). An analysis of grammatical errors among Iranian translation students: Insights from interlanguage theory. European Journal of Social Sciences, 25(4), 525-536.

Ahmadvand, M. (2008). Analyzing errors of Iranian EFL learners in their written productions. Retrieved from http://moslem17.googlepapers.com/Analysingerrorsof IranianEFLlearners.pdf

Brown, H. (2000). Principles of language learning and teaching. New York, NY: Addison Wesley Longman.

Corder, S. (1974). Idiosyncratic dialects and error analysis. IRAL, 9(1), 147-160.

Dulay, F., \& Burt, M. K. (1974). Theories of Second Language Learning. London: Edward Anorld Publishers.

Dulay, H., Burt, M., \& Krashen, S. (1982). Language two. Oxford, England: Oxford University Press.

Ellis, R. (2008). The Study of Second Language Acquisition. Oxford, England: Oxford University Press.

Ellis, R., \& Barkhuizen, G. (2005). Analysing learner language. Oxford, England: Oxford University Press.

Erdogan, V. (2005). Contribution of error analysis to foreign language teaching. Mersin University Journal of the Faculty of Education, 1(2), 261-270.

Gass, S., \& Selinker, L. (2008). Second language acquisition: An introductory course. Mahwah, NJ: LEA.

Halliday, M. A., \& R. Hassan. (1976). Language, Context, and Text: Aspects of Language in a Social-semiotic Perspective. Victoria: Deakin University.

Harmer, J. (1998). The practice of English language teaching (3rd ed.). London: Longman.

Hasyim, S. (2002). Error analysis in the teaching of English. Journal of Petra, 4(1), 42-50.

Hemchua, S., \& Schmitt, N. (2006). An Analysis of Lexical Errors in the English Compositions of Thai Learners. Prospect, 21(3), 3-25.

Ilomaki, A. (2005). Cross-linguistic influence: A Cross-sectional study with particular reference to Finnish-speaking learners of German. Unpublished master thesis, the Ohio State University, USA.

Jabbari, A. A., \& Fazilatfar, A. M. (2012). The role of error types and feedback in Iranian EFL classrooms. International Journal of English Linguistics, 2(1), 135-148. Retrieved from http://dx.doi.org/10.5539/ijel.v2n1p135

James, C. (1998). Errors in language learning and use: Exploring error analysis. London: Longman.

Keshavarz, M. D. (1999). Contrastive analysis and error analysis. Tehran: Rahnama Press.

Lennon, P. (1991). Error and the very advanced learner. IRAL, 29(1), 31-44. https://doi.org/10.1515/iral.1991.29.1.31

Lightbown, P. M., \& Spada, N. (2006). How languages are learned (2nd ed.). Oxford: Oxford University Press.

Lin, S. (2002). A case study of English writing competence of students at the Mei Ho Institute of Technology. Journal of Mei Ho Institute of Technology, 20, 180-206. 
Llach, M. P. A., Fontecha A. F., \& Espinosa, S. M. (2005). Differences in the written production of young Spanish and German learners: Evidence from lexical errors in a composition. Studia Linguistica, 61(1), 1-19. https://doi.org/10.1111/j.1467-9582.2007.00127.x

Mahmoud, A. (2011). The role of interlingual and intralingual transfer in learner-centered EFL vocabulary instruction. Arab World English Journal, 2(3), 28-49.

Nayernia, M. (2011). Writing errors, what they can tell a teacher? MJAL, 3(2), 200-218.

Nunan, D. (2001). Second Language Acquisition. In R. Carter \& D. Nunan (Eds.), The Cambridge Guide to Teaching English to Speakers of Other Languages (pp. 87-92), Cambridge: Cambridge University Press. https://doi.org/10.1017/CBO9780511667206.013

Randall, M. (2005). Factors affecting the spelling of primary school pupils in Singapore and pedagogic implications. Institute of Education. The British University in Dubai. Retrieved from http://www.crpp.nie.edu.sg/file.php/388/RRS05-005_final_version_.pdf

Richards, J. C., \& Schmidt, R. (2002). Dictionary of language teaching and applied linguistics. London: Longman.

Richards, J. C., Platt, J., \& Platt, H. (1992). Longman dictionary of language teaching and applied linguistics. Essex, England: Longman House.

Rybowiak, V. (1999). Error orientation questionnaire (EOQ): Reliability, validity, and different language $\begin{array}{lllll}\text { equivalence. Journal of Organizational } & \text { Behavior, } & 20, & 527-547 .\end{array}$ https://doi.org/10.1002/(SICI)1099-1379(199907)20:4<527::AID-JOB886>3.0.CO;2-G

Sadeghi, K. (2009). Collocational differences between L1 and L2: Implications for EFL learners and teachers. TESL Canada Journal, 26(2), 100-124. https://doi.org/10.18806/tesl.v26i2.417

Saeed, A., Ramazan, M., Gujjar, A., \& Iqbal, J. (2011). Gender Differences and L2 Writing. Language in India, 11(7), 1-10.

Sattari, A. (2012). An analysis of grammat ical errors in Iranian students' English writings. Iranian EFL Journal, $8(2), 143-157$.

Sattayatham, A., \& Honsa, S. (2007). Medical students' most frequent errors at Mahidol University, Thailand. Asian EFL Journal, 9(2), 170-194.

Shalaby, N. A., Yahya, N., \& El-Komi, M. (2009, January). Analysis of Lexical Errors in Saudi College Students' Compositions. Ayn, Journal of the Saudi Association of Languages and Translation, 2(3), 65-93.

Tahririan, M. H. (1986). Error awareness and advanced EFL learner's performance. RELC Journal, 17(2), 41-54. https://doi.org/10.1177/003368828601700203

Xie, F., \& Jiang, X. (2007). Error analysis and the EFL classroom teaching. US-China Education Review, 4(9), $1548-1559$.

Yaghoubi, A. (2009). Error competence and structural competence in EFL context. The Journal of Modern Thoughts in Education, 4(4), 91-110.

Yazdani, P., \& Ghafar, S. R. (2010). Involved or informative: A gender perspective on using pronouns and specifiers in EFL students' writing. MJAL, 2(5), 354-378.

Yin, C. C., \& Ung, D. C. (2001). Sub-stratum transfer among low proficiency students in written English. Unpublished master thesis, University Malaya, Malaysia.

\section{Copyrights}

Copyright for this article is retained by the author(s), with first publication rights granted to the journal.

This is an open-access article distributed under the terms and conditions of the Creative Commons Attribution license (http://creativecommons.org/licenses/by/4.0/). 